\title{
Efficient association of U2 snRNPs with pre-mRNA requires an essential U2 RNA structural element
}

\author{
Mary I. Zavanelli and Manuel Ares, Jr. \\ Sinsheimer Laboratories, University of California, Santa Cruz, Santa Cruz, California 95064 USA
}

To understand the role of U2 RNA structure in pre-mRNA splicing we have characterized several cold-sensitive mutations in an essential stem-loop of yeast U2. Although mutant $U 2$ is stable in vivo after a shift to restrictive temperature, splicing is rapidly inhibited, suggesting a direct effect on U2 function rather than U2 synthesis or snRNP assembly. Splicing complexes form at $23^{\circ} \mathrm{C}$ in both mutant and wild-type extracts; however, stable association of mutant $U 2$ snRNPs with pre-mRNA in vitro is inefficient at $15^{\circ} \mathrm{C}$, a temperature permissive for spliceosome assembly in wild-type extracts, indicating that the cold-sensitive defect is in U2 snRNP association with the assembling spliceosome. In vivo RNA structure probing reveals that the bulk of U2 RNA is misfolded in the mutants, even at permissive temperature. We propose that U2 stem-loop IIa is recognized by an assembly factor that assists U2 snRNP binding to pre-mRNA and that the cold sensitivity is due to a critical deficiency of correctly folded U2 for spliceosome assembly at low temperatures. Evolutionary conservation of the potential to form an interfering alternative RNA structure suggests the possibility that splicing could be regulated negatively at an early step by control of U2 snRNA conformation.

[Key Words: Splicing; spliceosome; cold-sensitive mutations; yeast]

Received August 21, 1991; revised version accepted October 8, 1991.

Removal of introns from nuclear pre-mRNA occurs in a large RNA-protein complex called the spliceosome (for reviews, see Steitz et al. 1988; Woolford 1989; Guthrie 1991; Ruby and Abelson 1991). Four small nuclear ribonucleoprotein particles (snRNPs), U1, U2, U4/U6, and U5, combine with pre-mRNA and each other in an ordered pathway to form the active complex. In mammals, the U2 snRNP associates with pre-mRNA early during complex formation at a site in the intron that includes the branchpoint (for review, see Steitz et al. 1988). The association of $\mathrm{U} 2$ with the intron requires $\mathrm{U} 2 \mathrm{AF}$ (Ruskin et al. 1988; Zamore and Green 1989) and is influenced by other proteins (Kramer 1988; Garcia-Blanco et al. 1989) that recognize the polypyrimidine tract in the intron to mediate U2 binding. Binding of mammalian U2 snRNPs can occur on transcripts lacking a $5^{\prime}$-splice site and in extracts where the $5^{\prime}$ end of U1 snRNA has been removed (Steitz et al. 1988), but some feature of the U1 snRNP may be required for U2 binding in mammalian extracts (Barabino et al. 1990). In both yeast and mammals, U2 RNA is required to base-pair near the intron branchpoint for efficient splicing to occur (Parker et al. 1987, Wu and Manley 1989; Zhuang and Weiner 1989).

The spliceosome assembly pathway in yeast extracts differs from that observed in mammalian cell extracts. In yeast, binding of the $U 2$ snRNP requires a conserved intron branchpoint sequence UACUAAC (Legrain et al.
1988; Ruby and Abelson 1988; Seraphin and Rosbash 1989|, as well as prior binding of the Ul snRNP (Ruby and Abelson 1988; Seraphin and Rosbash 1989|. There is no strong dependence on a polypyrimidine tract or the $3^{\prime}$-splice site for in vitro spliceosome assembly in yeast (Woolford 1989), although many yeast introns are U-rich in the region between the branchpoint and the 3 '-splice site (Parker and Patterson 1987), and changes in the pyrimidine content of this region can influence efficiency of $3^{\prime}$-splice site use in vivo (Patterson and Guthrie 1991). Of the yeast pre-RNA processing (prp) mutants (for review, see Guthrie 1991; Ruby and Abelson 1991), the PRP9 gene product has been shown to be required for stable association of the U2 snRNP with the pre-mRNA in vitro (Abovich et al. 1990). A fraction of U2 snRNPs in yeast splicing extracts can be immunoprecipitated by antibodies against an epitope-tagged $\operatorname{Prp} 9$ protein, suggesting it may mediate $\mathrm{U} 2$ addition to the assembling spliceosome as part of a complex that interacts directly with the U2 snRNP (Abovich et al. 1990). The PRP5 gene product, a putative RNA helicase (McFarland and Abelson 1989), is also reported to be required for this step (see McFarland and Abelson 1990; Ruby and Abelson 1991). In addition, there is evidence for a factor that recognizes the UACUAAC element before U2 snRNP binding (Seraphin and Rosbash 1989, 1991). The relationships between these yeast factors and proteins, such as mamma- 
lian U2AF, are unclear. Despite these differences, U2 RNA sequences are highly conserved, and mammalian U2 sequences can replace those of yeast for splicing in vitro (McPheeters et al. 1989) and in vivo (Shuster and Guthrie 1990; Miraglia et al. 1991).

What special features of the U2 snRNP are recognized by spliceosome assembly factors? The known U2-specific intrinsic snRNP proteins $A^{\prime}$ and $B^{\prime \prime}$ (for review, see Luhrmann 1988) would seem obvious candidates, but U2 snRNPs lacking the $A^{\prime}$ and $B^{\prime \prime}$ proteins function in splicing (Hamm et al. 1989; Pan and Prives 1989). Direct recognition of the RNA moiety of the snRNP is also possible; and thus far two RNA elements unique to $\mathrm{U} 2$ are known to be essential for U2 snRNP function in yeast: the branchpoint interaction region (nucleotides 32-39, Parker et al. 1987; Miraglia et al. 1991) and stem-loop IIa (nucleotides 48-67, Ares and Igel 1990). Both of these regions of U2 snRNA are highly conserved, and either of them could interact with an assembly factor during U2 binding to pre-mRNA. The branchpoint interaction sequence can be altered, and the snRNA will still function in splicing as a suppressor U2 (Parker et al. 1987, Wu and Manley 1989; Zhuang and Weiner 1989), suggesting that the primary sequence in this region has no conserved function besides base-pairing with the intron $/ \mathrm{Wu}$ and Manley 1989). Experiments with oligodeoxynucleotidetargeted RNase $\mathrm{H}$ digestion of U2 snRNPs (Steitz et al. 1988; Zillman et al. 1988) or the masking of parts of the snRNP with 2'-modified oligoribonucleotides (Barabino et al. 1989; Lamond et al. 1989) produce different answers to the question of the role in spliceosome assembly of either the branchpoint interaction element or the conserved sequences at the very $5^{\prime}$ end of U2 (which base-pairs with U6 snRNA; Hausner et al. 1990; Datta and Weiner 1991; Wu and Manley 1991). A possibility suggested by genetic analysis of U2 RNA is that stemloop IIa is required for binding of $\mathrm{U} 2$ snRNPs to premRNA early in spliceosome assembly (Ares and Igel 1990; Miraglia et al. 1991).

To study the role of U2 stem-loop IIa in splicing we have analyzed the effects of temperature on splicing in cold-sensitive yeast $\mathrm{U} 2$ mutations in vivo and in vitro.
We find that mutants carrying lesions in stem-loop IIa are cold sensitive for splicing in vivo. In splicing extracts made from cold-sensitive mutants, the formation of $\mathrm{U} 2$ snRNP-containing splicing complexes is also cold sensitive. The mutations disrupt the folded structure of $\mathrm{U} 2$ in vivo, but temperature-dependent changes cannot be detected. Taken together, the results indicate that efficient formation of an appropriate U2 RNA secondary structure is important for assembly of U2 snRNPs into splicing complexes and suggest that stem-loop IIa of U2 RNA is required for stable association of the U2 snRNP with pre-mRNA, perhaps through interaction with an assembly factor.

\section{Results \\ Growth phenotypes of point mutations in U2 stem-loop IIa}

Previous work indicated that non-Watson-Crick appositions in the 53-62 bp within stem-loop IIa of yeast U2 produce a recessive cold-sensitive or heat- and cold-sensitive growth phenotype on agar plates containing rich medium (Ares and Igel 1990). The positions of these mutations in the secondary structure model for yeast $\mathrm{U} 2$ are shown in Figure 1. The single-base changes have the following phenotypes on plates (Ares and Igel 1990): C62G, lethal; G53C, heat and cold sensitive, slow growing at $30^{\circ} \mathrm{C}$; G53A, cold sensitive; and C62U, cold sensitive. Compensatory double mutations G53C: C62G and G53A : C62U grow like wild type.

We examined the growth phenotypes of the G53A and C62U mutants in more detail. In rich liquid medium and on plates, strains carrying the cold-sensitive mutations continue to grow slowly at $18^{\circ} \mathrm{C}$, the restrictive temperature, but never achieve the cell density or colony size of wild type (not shown). Cells are not killed by long-term exposure to restrictive temperature because when cultures are shifted to restrictive temperatures or diluted and plated at permissive temperature, viable cell numbers are consistent with estimates of cell number with optical density measurements (not shown). Taken to-
Figure 1. Location of U2 stem-loop IIa mutations in the $U 2$ secondary structure. Alterations of the G53-C62 base pair are indicated. The heavy line indicates the phylogenetically conserved complementarity to the loop of stem-loop IIa. (bp int) Branchpoint interaction region; $(\mathrm{Sm})$ core snRNP proteinbinding site.

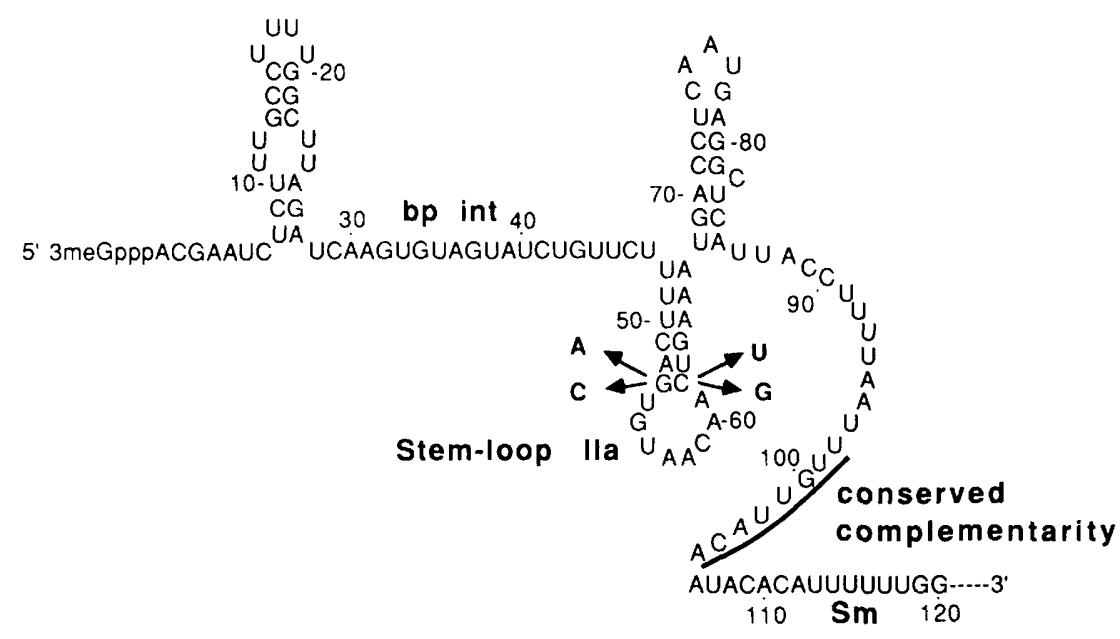


gether, the data indicate that the defect in the U2 mutants is reversibly inhibitory to growth rather than lethal.

\section{Splicing is cold sensitive in the U2 stem-loop IIa mutants}

To determine whether the cold-sensitive U2 RNA mutations have a direct effect on splicing, we isolated RNA from wild-type and mutant strains immediately after a shift from $30^{\circ} \mathrm{C}$ to restrictive temperature $\left(18^{\circ} \mathrm{C}\right)$ and examined the splicing of intron-containing transcripts. The U3A and U3B genes contain introns that differ in size by 27 nucleotides (Myslinski et al. 1990), allowing us to measure the levels of both pre-U3 transcripts in the same sample. An oligonucleotide complementary to the second exon of U3A and U3B was annealed to total RNA and extended with reverse transcriptase. Strains with wild-type $\mathrm{U} 2$ showed no change in the ratio of pre-U3 to mature U3 after the temperature shift (Fig. 2). The G53A and C62U single mutants contain slightly elevated levels of unspliced U3 transcripts at permissive temperature (Ares and Igel 1990), and upon a shift to restrictive temperature, the levels increase dramatically (Fig. 2). In the G53A : C62U compensatory double mutant, wildtype growth is restored (Ares and Igel 1990), and little or no accumulation of unspliced U3 is observed after temperature shift, indicating that the cold-sensitive splicing inhibition found in both single mutants is suppressed.

To compare the time course of splicing inhibition by the U2 RNA mutations with that of a known temperature-sensitive mutation affecting splicing, we shifted a prp4 strain carrying a heat-sensitive U4 snRNP protein (Banroques and Abelson 1990; Xu et al. 1990) from $23^{\circ} \mathrm{C}$ to $36^{\circ} \mathrm{C}$. Unspliced U3A accumulated to a similar extent in the prp4 strain as in the $\mathrm{U} 2$ mutants (Fig. 2, cf. lanes 7). The extent of pre-U3B accumulation on prp4 inactivation is less, most likely as a result of strain background differences in levels of U3B expression. We conclude that splicing of pre-U3 transcripts is inhibited in the U2 mutants soon after a shift to restrictive temperature.

U3 RNA is relatively stable; hence, we did not expect to see substantial immediate loss of spliced U3 as a result of inhibition of splicing. To determine whether splicing continued at low levels in the U2 mutants at restrictive temperature we assessed splicing of the first intron of the unstable MATa1 mRNA (Miller 1984). There is a rapid loss of mature MATa1 mRNA and the accumulation of pre-mRNA in a prp2 mutant after temperature shift (Miller 1984). We performed primer extension analysis in the presence of ddCTP in place of dCTP using an appropriate primer (Fig. 3). The MATa1 premRNA has no $G$ residues between the $3^{\prime}$ end of the primer and the $\mathrm{G}$ at the $3^{\prime}$-splice site of the first intron so that primer extension on MATa1 pre-mRNA gives a 38nucleotide product. MATa1 transcripts lacking the first intron should direct a 70-nucleotide termination product at the first $G$ upstream of the 5 -splice site (Astell et al. 1981). RNA isolated from our strain background yielded a 57-nucleotide product (Fig. 3) as a result of a polymorphism in the MATa1 first exon (M. Zavanelli, M. Ares, and R. Samaha, unpubl.; see also Miller 1984). The two cold-sensitive mutants G53A and C62U showed a rapid increase in the ratio of unspliced to mature transcript

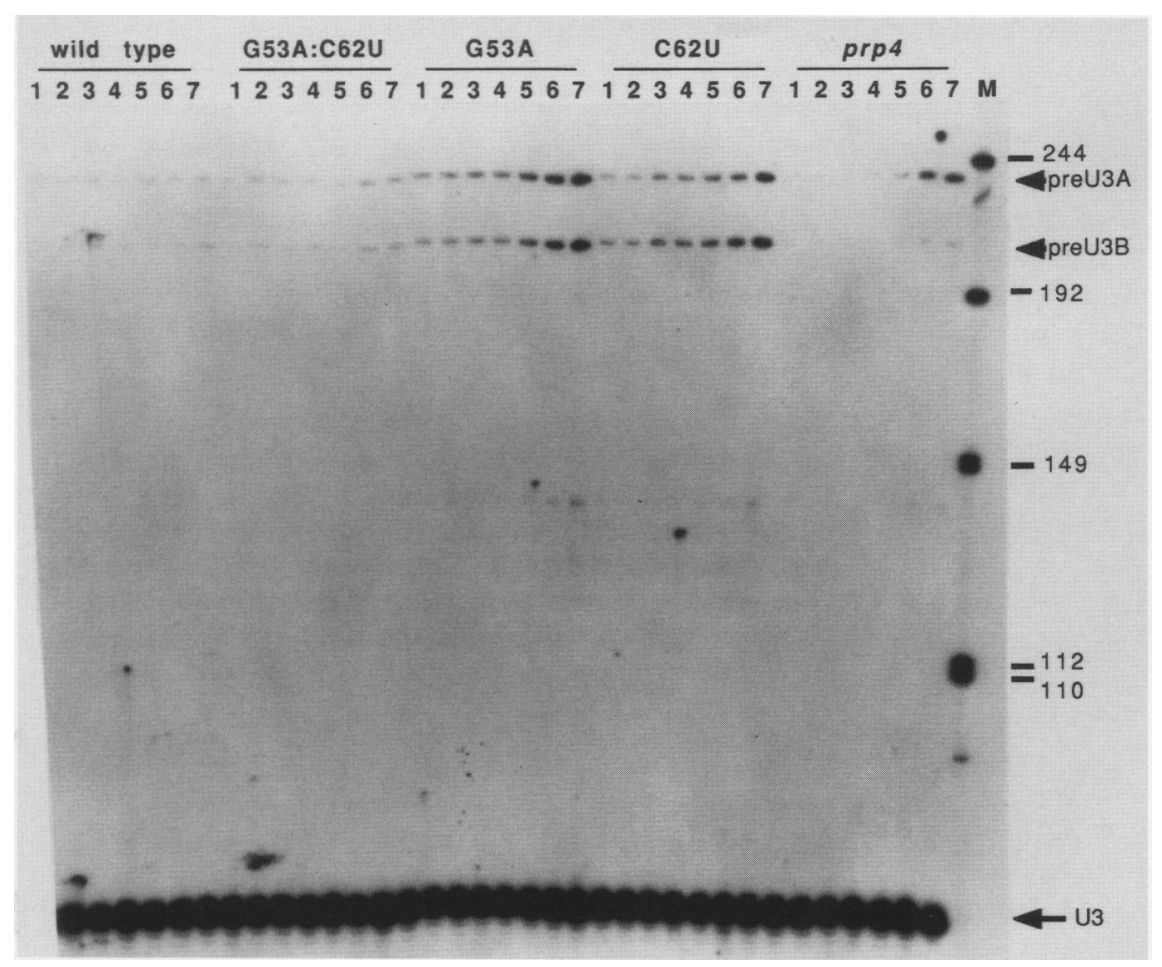

Figure 2. Inhibition of pre-U3 splicing with temperature shift in cold-sensitive U2 mutant strains. Cells were grown at $30^{\circ} \mathrm{C}$ and shifted to $18^{\circ} \mathrm{C}$ /wild type, G53A : C62U, G53A, and C62U) or grown at $23^{\circ} \mathrm{C}$ and shifted to $36^{\circ} \mathrm{C}$ (prp4) for 0 (lanes 1), 5 (lanes 2), 10 (lanes 3), 20 (lanes 4), 45 (lanes 5), 60 (lanes 6), or 120 (lanes 7) min. RNA was extracted and used in a primer extension assay with a labeled oligonucleotide complementary to the second exon of U3A and U3B genes. The arrow indicates the position of migration of U3; arrowheads indicate those of pre-U3 cDNAs. The product at $\sim 140$ does not correspond to any known U3 precursor or splicing intermediate and represents either a strong stop in one of the introns or a degradation product of pre-U3. Markers (lane $M$ ) are filled-in $\mathrm{HpaII}$ fragments of pUCl3. 
Figure 3. Inhibition of splicing of the $M A T \mathbf{a} 1$ gene first intron with temperature shift in cold-sensitive U2 mutant strains. Cells were grown at $30^{\circ} \mathrm{C}$ and shifted to $18^{\circ} \mathrm{C}$ /wild type, G53A : C62U, G53A, and $\mathrm{C} 62 \mathrm{U}$ ) or grown at $23^{\circ} \mathrm{C}$ and shifted to $36^{\circ} \mathrm{C}$ (prp4) for 0 (lane 1), 5 (lane 2), 10 (lane 3), 20 (lane 4), 45 (lane 5), 60 (lane 6), or 120 (lane 7) min. RNA was extracted and used in a primer extension assay with a labeled oligonucleotide complementary to the second exon of the MATa1 gene. The primer is positioned such that the first $G$ in the template encountered by the enzyme during primer extension is either the $G$ at the $3^{\prime}$ splice site (arrow, pre-mRNA) or either one of two Gs (depending on the MATa1 allele; see text) found in the first exon (arrows, mRNA). The reaction contains ddCTP in place of dCTP. Markers (lane $M$ ) are filledin Hpall fragments of pUCl3.

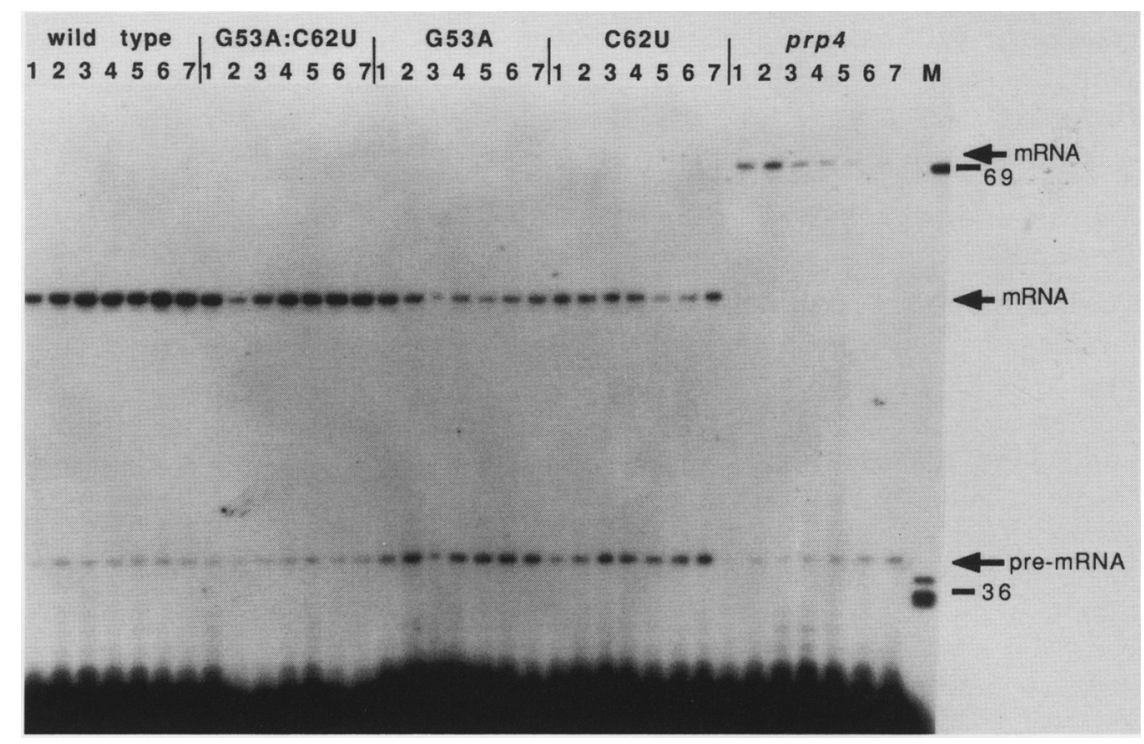

within 5-10 min after the shift to restrictive temperature (Fig. 3, cf. G53A lane 1 with G53A lanes 2 and 7). Complete loss of spliced MATa1 mRNA was not observed (G53A and C62U, lanes 7), even after much longer times (not shown). In contrast, splicing inhibition in the prp4 mutant was established more slowly, with kinetics similar to that observed by Miller (1984) for prp2; therefore, by $120 \mathrm{~min}$ spliced transcripts were not detectable (cf. G53A lane 7 and C62U lane 7 with prp4 lane 7). This is not the result of greatly different stabilities of MATa1 transcripts at $18^{\circ} \mathrm{C}$ versus $36^{\circ} \mathrm{C}$ because unspliced $M A T \mathbf{a} 1$ transcripts do not accumulate in wild type after a shift to $18^{\circ} \mathrm{C}$ (Fig. 3, wild type, lane 7), and the heatsensitive $U 2$ mutant G53C behaves like the cold-sensitive U2 mutants with respect to spliced and unspliced MATa1 RNAs after a shift to $36^{\circ} \mathrm{C}$ (not shown). Splicing of the MATa1 first intron in the G53A : C62U double mutant is unaffected by a shift to restrictive temperature, indicating that the splicing defects seen in the single mutants are suppressed by restoration of WatsonCrick base-pairing between the nucleotides at these positions (Fig. 3).

Although splicing is greatly inhibited in the U2 mutants, it is not completely blocked, suggesting that a U2 function before the first step of splicing is slowed in the mutants and has become growth rate limiting in the cold. To accurately determine the effectiveness of the cold-sensitive block is difficult owing to uncertainties about the rates of synthesis, splicing, or degradation of splicing precursors and products, as well as the activity of the critical components at permissive temperature and rapidity and extent of inactivation of these components after the temperature shift. Because the steadystate ratio of MATa1 pre-mRNA to mRNA in the mutants is greater than wild type at permissive temperature and increases to a maximum within 5-10 min after the temperature shift, we conclude that the inhibition of splicing is most likely the result of a direct effect of cold on the function of mutant U2. Primer extension experiments designed to detect accumulation of lariat-exon 2 splicing intermediates after a shift to restrictive temperature for a number of spliced transcripts (MATa1, RPL32, $C R Y 1$, actin/ showed no accumulation of such intermediates (data not shown), indicating that the $\mathrm{U} 2$ function rendered cold-sensitive in these mutants is required for the first step of splicing. We conclude that a $\mathrm{U} 2$ function before the first step of splicing is slowed in the mutants and has become growth rate limiting in the cold.

\section{Stability of mutant U2 is unaffected by shift to restrictive temperature}

U2 stem-loop IIa mutations do not affect U2 RNA stability at permissive temperature (Ares and Igel 1990). To exclude the possibility that the temperature-sensitive growth and splicing-inhibition phenotypes are the result of a rapid destabilization of the mutant U2 RNAs at the restrictive temperatures, we compared the steady-state levels of the mutant RNA to pseudo-wild-type U2 RNA at 30,18 , and $36^{\circ} \mathrm{C}$ (Fig. 4). The pseudo-wild-type U2 has a $\mathrm{C} \rightarrow \mathrm{U}$ change at position 121 that does not significantly affect U2 RNA accumulation or function and allows discrimination of two different U2 RNAs in a mixture (Ares and Igel 1990). The cold-sensitive mutant U2 RNAs accumulate to equivalent levels with respect to the pseudo-wild-type $\mathrm{U} 2$ at all temperatures (Fig. 4). Therefore, a decrease in the level of mutant U2 RNA at the restrictive temperatures is not responsible for the temperature-sensitive growth or splicing-inhibition phenotype.

Association of U2 snRNPs with pre-mRNA is cold-sensitive in splicing extracts from the mutants

To identify the U2 function compromised by disruption of stem-loop IIa, we prepared splicing extracts from iso- 


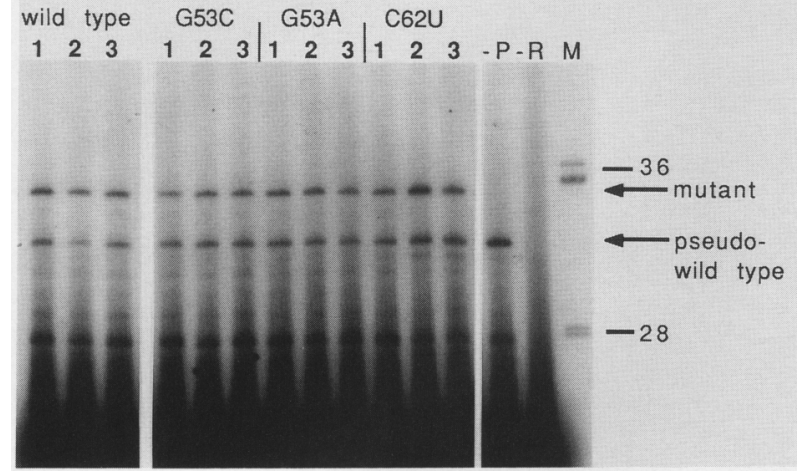

Figure 4. Steady-state levels of cold-sensitive mutant U2 RNA at different temperatures. Plasmids containing wild-type, G53C, G53A, or C62U U2 genes were introduced into a haploid yeast strain containing a pseudo-wild-type U2 gene marked by the $\mathrm{C} 121 \mathrm{U}$ mutation. Cultures were grown at either $30^{\circ} \mathrm{C}$ (lanes 1), $18^{\circ} \mathrm{C}$ (lanes 2 ), or $36^{\circ} \mathrm{C}$ (lanes 3). A control strain with only the $\mathrm{U} 2 \mathrm{C} 121 \mathrm{U}$ plasmid was grown at $30^{\circ} \mathrm{C}$ (lane $-P$ ). RNA was extracted and used in a primer extension assay with a U2 primer (23T) placed so that the first $U$ in the template encountered by the enzyme is either U121 (arrow, pseudo-wild type) or U118 (arrow, mutant). The reaction contains ddATP in place of dATP. A reaction without template is shown (lane $-R$ ). Markers (lane $M$ ) are end-filled HpaII fragments of pUCl3. All lanes are from the same gel; intervening lanes were cut out.

genic strains containing mutant $\mathrm{U} 2$. Strain BJ81 contains a wild-type U2-coding region fused to a $G A L$-regulated promoter in the chromosome (Miraglia et al. 1991) and is galactose dependent unless a functional, constituitively expressed $\mathrm{U} 2$ gene is present on a plasmid. After the desired U2 mutation is introduced, the strain is grown on glucose at permissive temperatures, and only the mutant $\mathrm{U} 2$ accumulates in the cell. Extracts are prepared as usual at $4^{\circ} \mathrm{C}$ (Lin et al. 1985) and are active when assayed at $23^{\circ} \mathrm{C}$, indicating that the cold treatment necessary for the extraction procedure does not irreversibly inactivate the mutant U2 (Fig. 5A,B). The experiments presented in Figure 5 were performed using the same wild-type and mutant extracts and have been repeated with multiple C62U and G53A extracts. We have not observed coldsensitive splicing or splicing complex formation in any wild-type extract.

Using a labeled actin pre-mRNA similar to that described by others, we assayed splicing (Lin et al. 1985). RNA was extracted at times after initiation of the splicing reactions and separated on denaturing gels to evaluate reaction of the pre-mRNA. Splicing intermediates and products are detected within $5 \mathrm{~min}$ in wild-type extracts at $23^{\circ} \mathrm{C}$ (lane 4 ) but are not apparent until $10 \mathrm{~min}$ in either wild-type extracts at $15^{\circ} \mathrm{C}$ (lane 5 ) or mutant extracts at $23^{\circ} \mathrm{C}$ (lane 5 ) nor in mutant extracts at $15^{\circ} \mathrm{C}$ until between 10 and $20 \mathrm{~min}$ of incubation (lane 6). The delayed appearance of splicing intermediates and products suggested that an early step in the process, perhaps spliceosome assembly, might be cold sensitive.

We monitored spliceosome assembly by native gel electrophoresis and could detect splicing complexes identified and characterized by others (Pikielny and Rosbash 1986; Pikielny et al. 1986; Cheng and Abelson 1987; Seraphin and Rosbash 1989, 1991). The collection of complexes in bracket 1 (Fig. 5B) form late in the reaction (including a species containing the splicing intermediates and products; data not shown) and are equivalent to the A complexes of Cheng and Abelson (1987) and complexes I and II of Pikielny et al. (1986), and contain the U2, U4/U6 or U6, and U5 snRNPs (Pikielny et al. 1986; Cheng and Abelson 1987). The complex in bracket 2 is equivalent to the B complex (Cheng and Abelson 1987) or complex III (Pikielny et al. 1986), which contains U2, but not U4/U6 or U5 (Pikielny et al. 1986; Cheng and Abelson 1987). This complex contains unreacted precursor and requires ATP for its formation (Pikielny et al. 1986; Cheng and Abelson 1987; data not shown). The complex in bracket 3 also contains unreacted precursor, does not require ATP for formation (not shown), and may represent commitment complexes (Seraphin and Rosbash 1989, 1991).

Splicing reactions were carried out at two temperatures $\left(23^{\circ} \mathrm{C}\right.$ and $\left.15^{\circ} \mathrm{C}\right)$ and sampled at times after the addition of the splicing extract to the reaction (Fig. 5B). Complexes in bracket 3 form early and efficiently in both mutant and wild-type extracts, suggesting that this step in splicing complex formation is unaffected by the U2 mutations. This is consistent with the representing commitment complexes that form in U2-depleted extracts as described by Seraphin and Rosbash $(1989,1991)$. The first U2-containing complex (bracket 2) can be detected after $1 \mathrm{~min}$ in wild-type extracts at $23^{\circ} \mathrm{C}$ (Fig. 5B, wild type at $23^{\circ} \mathrm{C}$, lane 2) and within $2 \mathrm{~min}$ in either mutant extracts at $23^{\circ} \mathrm{C}$ (lane 3 ) or wild-type extracts at $15^{\circ} \mathrm{C}$ (lane 3 ). In mutant extracts at $15^{\circ} \mathrm{C}$, however, substantial amounts of this complex never form (lanes 1-7). These observations indicate that the stable addition of U2 snRNPs to the assembling spliceosome is cold sensitive in mutant extracts. Formation of bracket 1 complexes is also delayed and inefficient in mutant extracts at $15^{\circ} \mathrm{C}$ (lanes $5-7$ ). These complexes are visible by $5 \mathrm{~min}$ in mutant and wild-type extracts at $23^{\circ} \mathrm{C}$ (lane 4 ), form more slowly in wild-type extracts at $15^{\circ} \mathrm{C}$ (lane 5), and are detected at low levels in mutant extracts at $15^{\circ} \mathrm{C}$ (lanes 5-7). Given the proposed dependence of the formation of bracket 1 complexes on the assembly of the bracket 2 complex (Pikielny et al. 1986; Cheng and Abelson 1987), it is likely that the inhibition of formation of these complexes is the result of the impact of temperature on the formation of the first U2-containing complex.

Estimates of initial rates of complex formation in these extracts using densitometry suggest that $\mathrm{C} 62 \mathrm{U}$ mutant extracts assemble U2-containing complexes only twofold more slowly than wild type at $23^{\circ} \mathrm{C}$, but more than fivefold more slowly at $15^{\circ} \mathrm{C}$. That is, wildtype extracts assemble U2-containing complexes at a rate almost 6 -fold lower at $15^{\circ} \mathrm{C}$ than at $23^{\circ} \mathrm{C}$, whereas the mutant extracts assemble U2-containing complexes nearly 15 -fold more slowly at $15^{\circ} \mathrm{C}$ than at $23^{\circ} \mathrm{C}$. Because 

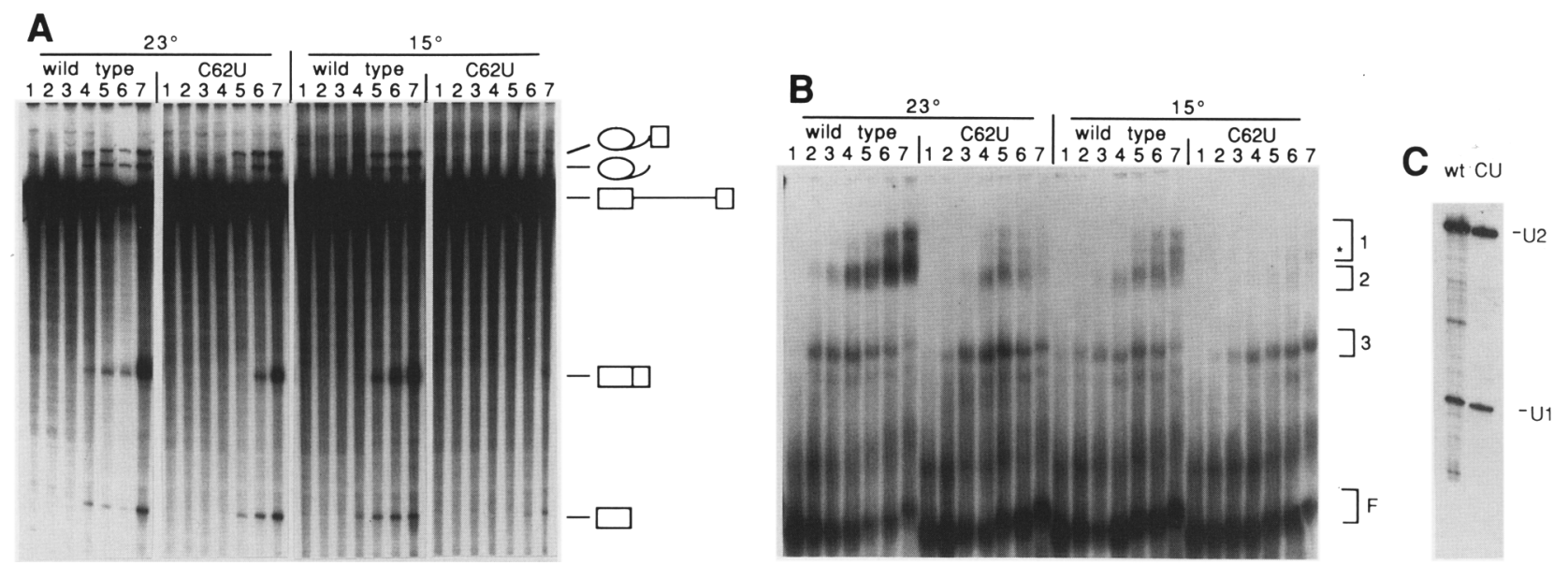

Figure 5. Splicing is cold sensitive in extracts from U2 stem-loop IIa mutants. $(A)$ Time course of substrate reaction in mutant and wild-type splicing extracts at different temperatures. Splicing reactions were assembled using a labeled actin pre-mRNA and extracts from the indicated strains, incubated at the indicated temperatures and sampled at 0 (lanes 1), 1 (lanes 2), 2 (lanes 3), 5 (lanes 4), 10 (lanes 5), 20 (lanes 6), and 40 (lanes 7) min. RNA was extracted and separated on a denaturing gel by electrophoresis. Positions of migration of the precursor, intermediates, and products are indicated at right. All samples are from the same experiment: A photograph of the autoradiogram was cut and rearranged to present positions as in $B$. (B) Time course of splicing complex formation in mutant and wild-type splicing extracts at different temperatures. Splicing reactions were assembled using a labeled actin pre-mRNA and extracts from the indicated strains, incubated at the indicated temperatures, and sampled at 0 (lanes 1), 1 (lanes 2), 2 (lanes 3), 5 (lanes 4), 10 (lanes 5), 20 (lanes 6), and 40 (lanes 7 ) min. Samples were taken, quenched, and loaded on a native acrylamide-agarose gel to separate splicing complexes. Complexes labeled in brackets 1,2 , and 3 are discussed in the text. Bracket $F$ indicates the position of migration of naked substrate RNA. $|C|$ Mutant $\mathrm{U} 2$ is abundant in splicing extracts. RNA was extracted from the indicated splicing extracts and used in a primer extension reaction with two labeled primers: one complementary to U1 and the other complementary to U2. Positions of migration of full-length primer extension products derived from U1 and U2 RNAs are indicated.

multiple components and multiple steps are required to assemble a U2-containing complex (for review, see Ruby and Abelson 1991), a lack of understanding of which, if indeed the same, step is rate limiting in the two extracts, and the relationship of splicing complex formation rate in vitro to splicing rate in vivo complicates interpretation. Nonetheless, the results indicate that extracts made from the cold-sensitive U2 mutant are differentially impaired for in vitro splicing complex formation in the cold and suggest that U2 snRNP addition to the assembling spliceosome is the cold-sensitive step.

After $40 \mathrm{~min}$ of incubation, the amount of splicing intermediates and products generated in the mutant and wild-type extracts at $15^{\circ} \mathrm{C}$ was similar, in spite of the dramatic inhibition of complex formation. This is because the amount of pre-mRNA participating in complex formation in our wild-type extracts greatly exceeds the amount that eventually becomes spliced, probably because a factor required for the splicing reactions, but not for splicing complex formation, is limiting. The small amounts of U2-containing complexes that form inefficiently in the mutant extracts are sufficient to produce amounts of splicing intermediates and products similar to that observed in wild-type extracts where splicing complex formation is efficient. This indicates that although the capacity of the extract for the substrate cleavage-ligation reactions is only modestly affected, the efficiency of stable association of U2 snRNPs with premRNA in vitro is reduced dramatically by the stem-loop IIa mutations at low temperatures.
To exclude the possibility that mutant U2 RNA is poorly represented or unstable in mutant splicing extracts, we measured amounts of U2 RNA present in wild-type and mutant splicing extracts (Fig. 5C). As an internal control, we monitored the amounts of UI RNA. There are equivalent concentrations of both $U 2$ and $U 1$ RNAs in both the wild-type and the C62U splicing extracts used for the experiments in Figure 5, A and B, as well as others (not shown), indicating that the in vitro splicing defect is not due to poor extractability or representation of U2 snRNA in mutant extracts.

\section{The secondary structure of the bulk of mutant U2 RNA is perturbed in a temperature-independent fashion}

To determine whether conditional U2 function might be correlated with changes in the conformation of U2 during a shift to restrictive temperatures, we probed the structure of $\mathrm{U} 2$ in vivo using dimethylsulfate (DMS). DMS reacts with N1 of adenosines and N3 of cytosines, which are not involved in base-pairing (Inoue and Cech 1985; Moazed et al. 1986) and can be applied to live yeast cells for RNA structure-probing purposes (Ares and Igel 1990).

We analyzed the $5^{\prime}$ domain of U2 RNA in the wildtype and mutant strains grown at the permissive temperature of $30^{\circ} \mathrm{C}$ or shifted to $18^{\circ} \mathrm{C}$ or $36^{\circ} \mathrm{C}$ (Fig. $6 \mathrm{~A}$ ). Nucleotides in the complementary sequences required to form stem-loop IIa are relatively protected from reac- 
tion with DMS, whereas the loop nucleotides are reactive, consistent with the existence of this stem-loop in a large fraction of wild-type $\mathrm{U} 2$ molecules in vivo, at least at $30^{\circ} \mathrm{C}$ (Ares and Igel 1990; Fig. 6A, wild-type, lane 2). The nucleotides in the phylogenetically conserved complementarity to the loop (Fig. 1) are also reactive (Fig. 6A and $\mathrm{B}$ ), in agreement with genetic experiments showing that this complementarity is dispensable, and, hence, cannot be absolutely required to pair with the loop during the function of U2 in splicing (Ares and Igel 1990). The wild-type pattern of nucleotide accessibility observed at $30^{\circ} \mathrm{C}$ is also observed at 18 and $36^{\circ} \mathrm{C}$ (Fig. $6 \mathrm{~A}$, wild type, lanes $2-4$ ).

Changes in the reactivities of residues in the single mutants at $30^{\circ} \mathrm{C}$ are very apparent and do not change detectably with temperature (Fig. 6A). For both the
G53C and G53A mutations, there is a loss of reactivity of residues A57, A58, and C59. Increased reactivity of C51 and A52 is also observed, as well as at position 53 where an unreactive $G$ residue has been replaced with $A$ or $\mathrm{C}$, in both cases introducing unpaired, DMS-reactive nucleotides. In addition, there is decreased reactivity of A103 and C104 in both of these mutants (Fig. 6A). These data are consistent with disruption of at least part of the stem of stem-loop IIa and pairing of the loop with residues in the conserved complementarity, as depicted in Figure $6 \mathrm{C}$, causing the bulk of the $\mathrm{U} 2$ to be folded into a structure similar to that proposed by Keller and Noon (1985; Fig. 6C).

In the C62U mutant, a decrease in the reactivity of A57, A58, and C59 is also detected; however, there is also a loss of reactivity of A60 and A61 and a less signif-

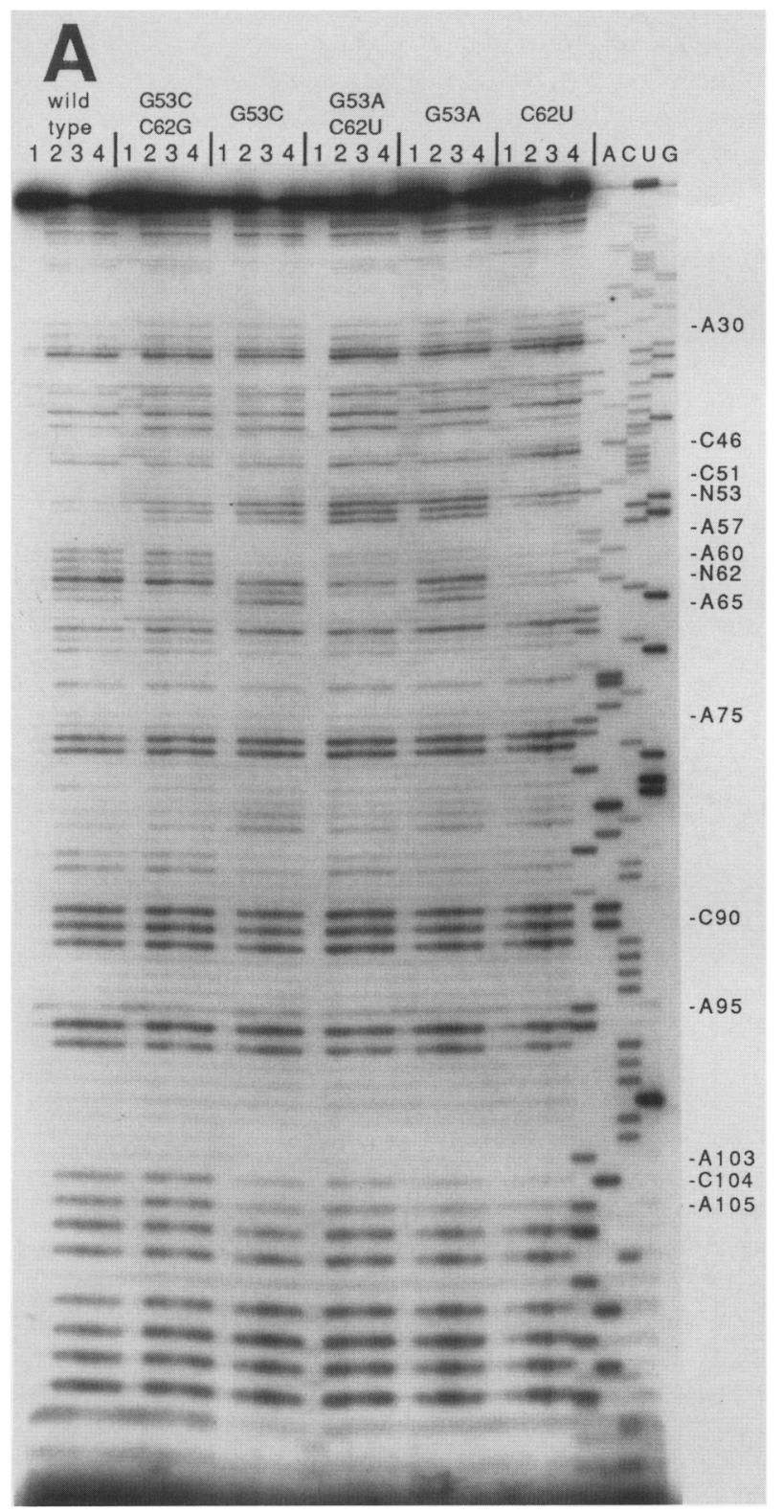

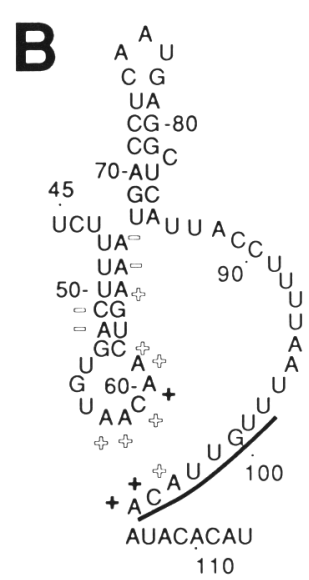

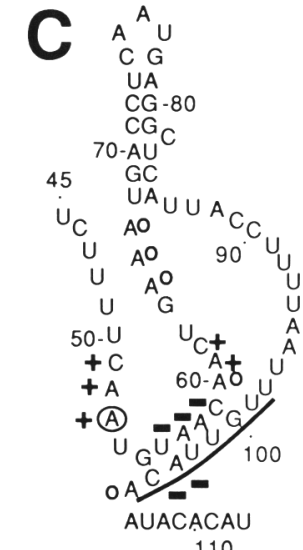

110
Figure 6. Altered secondary structure in U2 mutants. $(A)$ DMS reactivity of individual nucleotides in wild-type and mutant $U 2$. Cells with the indicated $U 2$ genes were incubated at $30^{\circ} \mathrm{C}$ (lanes 1,2 ) $18^{\circ} \mathrm{C}$ (lanes 3), or $36^{\circ} \mathrm{C}$ (lanes 4) for $4 \mathrm{hr}$ and treated with DMS for $2 \mathrm{~min}$, and the reaction was stopped (lanes 2-4); or they were incubated without DMS and then treated with stop solutions before the addition of DMS (stop control, lanes 1). RNA was extracted and sites of modification were mapped relative to an RNA sequence ladder generated by primer extension using unmodified wild-type U2 RNA and dideoxynucleoside triphosphates. (Lane $A$ ) Reaction contained ddTTP; (lane $C$ ) ddGTP; (lane U) ddATP; (lane G) ddCTP. Position of migration of the dideoxynucleotide-generated termination products for selected nucleotides are indicated at right. Note that DMS modification-induced termination products are 1 nucleotide shorter than the corresponding dideoxynucleotide termination product. $|B|$ DMS reactivities of nucleotides in stem-loop IIa and the conserved complementarity. Sequence from position $45-113$ is shown. Relative reactivity is indicated as follows: (Solid minus) Strongly protected; (open minus) protected; (open plus) reactive; (solid plus) strongly reactive. $(C)$ Changes in reactivity and alternative folding in the G53A mutant. Sequence from position $45-113$ is shown, with the mutant position circled. Changes in reactivity are indicated as follows: $(+)$ Increased reactivity; $(-1$ decreased reactivity; $(0)$ little or no change in reactivity. A65, A66, and A67 are not shown pairing but could be paired, as discussed in the text. 
icant gain of reactivity in C51 and A52 (Fig. 6A). Because the residue at position 62 was changed from a $\mathrm{C}$ to an unreactive $\mathrm{U}$, we are unable to determine how this residue is affected. The C62U mutation extends the potential for base-pairing an additional $2 \mathrm{bp}$ and, hence, may stabilize a protecting interaction between $\mathrm{A} 60$ and U99, and between $\mathrm{A} 61$ and $\mathrm{U} 98$ (Fig. 6C). Because the reactivity of 6 nucleotides decreases (A57, A58, C59, A60, $A 103$, and C104) and only 2 increase slightly (C51 and A52) in the C62U mutant (Fig. 6A), it is possible that both helices form simultaneously in a pseudoknot (Pleij et al. 1985; Puglisi et al. 1988; Ares and Igel 1989).

There is little change in the reactivities of A66 or A67 in any of the mutants, suggesting that either the mutations do not disrupt the potential interactions with U49 and $\mathrm{U} 48$ (and also produce a pseudoknot) or that they pair elsewhere, perhaps with U87 and U86 (see Fig. 6C). For unknown reasons $\mathrm{A} 65$ is more reactive than might be expected of a paired A residue even in wild type, making the significance of its high reactivity in the mutants difficult to interpret.

The wild-type pattern of reactivity is only incompletely restored in both the compensatory double mutants G53C : C62G and G53A : C62G (Fig. 6A). Reactivities of residues $57-61$ in the loop of stem-loop IIa, as well as A103 and C104 in the conserved complementarity are restored to near wild-type levels in the double mutants, indicating that the alternative folding depicted in Figure 6C is suppressed. In contrast, the increased reactivity of $\mathrm{C} 51$ and $\mathrm{A} 52$ observed in the single mutants is not suppressed, suggesting that the stem may form less efficiently in these double mutants than in wild type, although neither strain is temperature sensitive.

It is important to note that in instances where two or more distinct folded forms are present in roughly equal amounts, the patterns of reactivity will be superimposed, making structure description difficult. The predominant misfolded forms consistent with the structure-probing data (Fig. 6A) are similar to those proposed previously for $\mathrm{U} 2$ structure based on phylogenetic considerations (Keller and Noon 1985; Ares and Igel 1989). The mutations could affect protein binding, and this might account for some of the alterations in DMS reactivity, further complicating the interpretation of the nucleotide reactivities. In spite of these difficulties, none of the effects on U2 RNA structure in the single mutants is influenced in a dramatic way by temperature, suggesting that cold sensitivity is not due to the conversion of the bulk of $\mathrm{U} 2$ from a correctly folded form at permissive temperature to a misfolded, nonfunctional form at restrictive temperature. We conclude that the main impact of these mutations on U2 RNA structure is the temperature-independent disruption of stem-loop IIa.

\section{Discussion}

We have characterized several point mutations in U2 snRNA that are cold sensitive for growth and splicing. We have shown that unspliced transcripts accumulate soon after a shift to restrictive temperature (Figs. 2 and 3 ), but that in contrast to the heat-sensitive U4 snRNP mutant prp4, the cold-sensitive U2 mutants continue splicing at reduced rates at restrictive temperature (Fig. 3). Association of U2 snRNPs with actin pre-mRNA transcripts is impaired in mutant splicing extracts in the cold (Fig. 5), indicating that the stem-loop IIa structure perturbed by the mutations is essential for this association. Surprisingly, the secondary structure perturbations caused by the mutations are largely temperature independent, suggesting that either a small fraction of U2 need be correctly folded for function or that there is sufficient interconversion of folded forms to supply spliceosome assembly reactions (Fig. 6).

\section{A U2 RNA secondary structure is required for association of U2 snRNPs with pre-mRNA}

Mutations in stem-loop IIa cause several phenotypes that allow an important RNA structure-function correlation to be made. Alteration of the Watson-Crick base pair between $\mathrm{U} 2$ nucleotides 53 and 62 causes the bulk of U2 snRNA in the cell to be folded differently from wild type and in a fashion that disturbs the integrity of stemloop IIa (Fig. 6), an essential structure (Ares and Igel 1990|. Disruption of stem-loop IIa is accompanied by reduced rates of splicing in vivo (Ares and Igel 1990), especially at restrictive temperatures (Figs. 2 and 3), as well as inefficient association of U2 snRNPs with premRNA at restrictive temperatures in vitro (Fig. 5). These data argue that stem-loop IIa is required for U2 snRNP association with pre-mRNA during spliceosome assembly.

The stem-loop may function by interacting with one or more splicing factors reported to be required for U2 snRNP binding to the assembling spliceosome (Abovich et al. 1990; Ruby and Abelson 1991). The PRP9 gene product is required for U2 snRNP-containing complexes to form in vitro, and a fraction of U2 snRNPs are precipitated by an antibody against an epitope-tagged Prp9 fusion protein (Abovich et al. 1990). It has been argued that Prp9 does not fit the definition of a U2 snRNP protein; hence, a reasonable hypothesis is that $\operatorname{Prp} 9$ protein is a spliceosome factor that associates with the fraction of U2 snRNPs participating in splicing (Abovich et al. 1990). The PRP5 gene product is reported to be required for U2 snRNP participation in splicing complexes in vitro (Ruby and Abelson 1991), and either of these could also be involved in a direct physical interaction with stem-loop IIa or as part of a complex that must interact with stem-loop IIa. Prp9 has a zinc finger-like motif possibly associated with RNA binding (Legrain and Choulika 1990), whereas Prp5 has the DEAD signature of RNA helicases (for reviews, see Ruby and Abelson 1991; Guthrie 1991). Additional experiments will be required to determine which, if any, of these components may interact directly with stem-loop IIa. Because of the broad phylogenetic conservation of the stem-loop Ila sequence (Guthrie and Patterson 1988; Ares and Igel 1989, 1990), 
structural elements of components interacting with it may also be conserved.

Mutations in stem-loop IIa could conceivably block function in one or both of two ways. First, a mutation could cause a structural distortion of the stem owing to the presence of a mismatched base pair. This distortion could reduce binding by spliceosome assembly factors that might interact with the stem-loop. Alternatively, and consistent with the structure-probing data (Fig. 6), a mutation could block efficient formation of stem-loop IIa such that only a small fraction of U2 molecules in the cell were folded to contain it (albeit in distorted form), and this population might be too small to support efficient splicing. In the second model, the absence of the stem-loop IIa, rather than a subtle alteration of its structure, causes the defect. Additional experiments will be necessary to determine whether one or both of these mechanisms are at work.

\section{RNA misfolding and cold sensitivity}

How do mutations in stem-loop IIa render U2 snRNP function in spliceosome assembly cold-sensitive (Figs. 2, 3 , and 5) and yet cause temperature-independent misfolding (Fig. 6)? A heat-sensitive phenotype might have been expected of a mutation predicted to decrease the thermal stability of an essential RNA helix. Why do mutant strains grow almost as well as wild-type strains at permissive temperature even though most of their $U 2$ is misfolded? This apparent conflict can be reconciled by a kinetic hypothesis (Fig. 7). In this model, U2 RNA is in a state of kinetic interconversion or flux between alternatively folded forms in vivo (and in splicing extracts), only one of which can function in assembly. This inter- conversion might or might not require an enzyme and would produce a characteristic steady-state population distribution, which could be sampled in a structureprobing experiment. Near equilibrium, the most stable forms will predominate, and the distribution will be altered by mutations that change the relative stabilities of alternatively folded forms. If the rate of interconversion is high, a functional conformation may occur with sufficient frequency to supply spliceosome assembly reactions with correctly folded $\mathrm{U} 2$ at permissive temperature. In the cold, the rate of interconversion could be expected to drop, without appreciably affecting the steady-state distribution. The spliceosome assembly reactions would rapidly deplete the small pool of correctly folded U2 snRNPs, interconversion would be too slow to replenish it, and $\mathrm{U} 2$ refolding would become the growth rate-limiting step.

Kinetic data on rates of simple interconversion between alternative RNA secondary structures with equivalent or similar stabilities are not extensive. Neither are data on the effects of temperature on such rates, although practically speaking, low temperatures are used to stabilize nucleic acid structure in the laboratory (e.g., see Williamson et al. 1989|, whereas heat treatment can be used to renature and "activate" RNA molecules that have adopted nonfunctional structures (e.g., see Walstrum and Uhlenbeck 1990 and references therein). It is possible that there is little or no interconversion and that the cold-sensitive step is the addition of the U2 snRNP to the prespliceosome. In this case, the natural cold sensitivity of this step would be masked by an excess of correctly folded U2 in wild-type cells and become apparent only when a limited amount of correctly folded $U 2$ is available, as in the mutants.

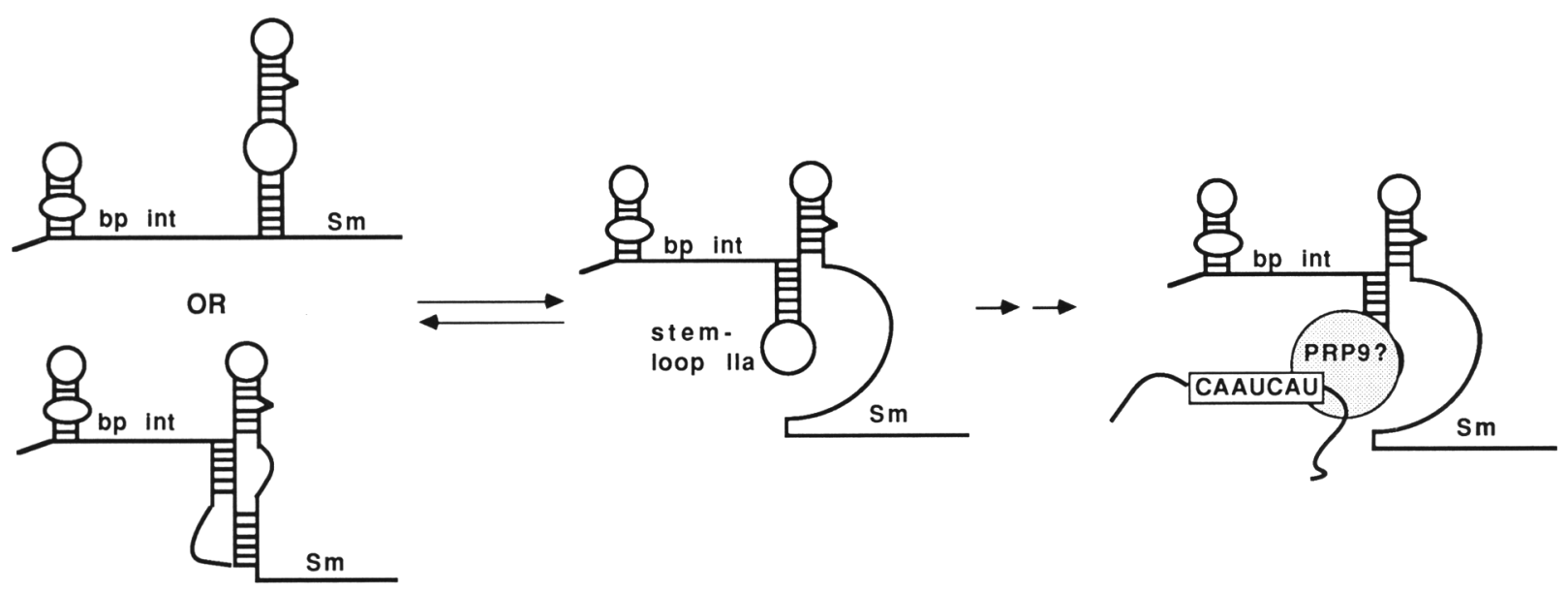

Figure 7. Model for early steps in U2 snRNP assembly into splicing complexes. In wild type, most U2 is folded to contain stem-loop II (middle). Spliceosome assembly factors, perhaps including Prp 9 protein, interact with stem-loop IIa to bind U2 to the assembling spliceosome near the pre-mRNA branchpoint (right). U2 folded to contain stem-loop IIa (middle) is in flux with alternatively folded forms (left), owing to interconversion. Mutations that reduce the stability of stem-loop Ila relative to the competing helix that could form between the loop and the conserved complementarity will drive the distribution to the left, and most of the U2 in the cell will not contain stem-loop IIa. At high temperatures, interconversion is efficient, and although present in small steady-state amounts, sufficient U2 containing stem-loop IIa is continuously generated by interconversion to feed the spliceosome assembly reactions. At low temperature in the mutants, the rate of interconversion drops and splicing is inhibited. 


\section{What is the role of the competing helix?}

The unusual presence of a potentially interfering, dispensable, yet highly conserved complementarity within the U2 structure is enigmatic. Phylogenetic analysis reveals multiple compensating base changes that preserve complementarity with the loop of stem-loop IIa (Guthrie and Patterson 1988; Ares and Igel 1989), and yet this complementarity is dispensable (Ares and Igel 1990). Even in U2 RNA from divergent eukaryotes, such as trypanosomes and their relatives (Hartshorne and Agabian 1990; Tschudi et al. 1990), an analogous, conserved complementarity persists (M. Ares, unpubl.). This argues that some feature of U2 RNA function is enhanced by conservation of an alternative RNA structure that disrupts stem-loop Ila. Previously, we suggested that positive U2 function could be augmented by this structure but that its contribution could not be essential for splicing (Ares and Igel 1990). It is also possible to conceive a general negative regulatory role for this sequence, given its conservation and the structure-probing data suggesting that it participates in a helix at the expense of stemloop IIa in the mutants (Fig. 6). A factor sensitive to a signal indicating that splicing is to be turned off might direct the interconversion of the U2 snRNPs in the cell to an alternatively folded, nonfunctional conformation, and splicing would be shut off rapidly at an early step. Regulation of RNA function by alternative secondary structures has been implicated in translation of $\lambda$ cIII mRNA, which influences the lysis-lysogeny decision after infection (Altuvia et al. 1989), as well as in the replication control of ColEl plasmids (Masukada and Tomizawa 1986). If such a system operates on $U 2$, the need for general negative regulation of splicing (and trans-splicing that requires U2; Tschudi and Ullu 1990) must also be conserved. So far, the only environmental stimulus reported to invoke a general inhibition of splicing is heat shock (Bond 1988; Muhich and Boothroyd 1988; Shukla et al. 1990; Delannoy and Caruthers 1991; Yost and Lindquist 1991). In any event, the availability of yeast U2 mutants lacking this complementarity provides experimental approaches to these questions.

\section{Materials and methods}

Yeast strains

All strains were grown according to standard procedures (Sherman et al. 1986). For the in vivo analysis of splicing inhibition and structure probing we used an isogenic set of strains generated by plasmid shuffling and varying only in the U2 allele they carry on a centromeric LEU2 plasmid (Ares and Igel 1990). They are MATa, leu2-3,112, ura3-52, his4-619, lys2, and snr20::URA3 carrying YCpU2 with the indicated allele. For the RNA stablity experiments the strains also carry a LYS2 centromeric plasmid with a pseudo-wild-type U2 allele marked by the C121U mutation as an internal U2 RNA stability reference /Ares and Igel 1990). As indicated, this strain background has a polymorphic a allele at the $M A T$ locus. The temperature-sensitive splicing mutant containing the prp4 allele was obtained from the Yeast Genetic Stock Center (Berkeley, CA) and expresses a MATa allele consistent with the published sequence (Astell et al. 1981; see also Miller 1984).
For splicing extracts, an isogenic set of strains based on BJ81 was used. BI81 is MATa, GAL2, leu2-3,112, ura3-52, trp1, pep43, prb1, prc1, and contains a glucose-repressible wild-type U2 allele integrated into the chromosome (Miraglia et al. 1991). When transformed with the appropriate $U 2$ allele on a centromeric $L E U 2$ plasmid and grown on glucose, only the plasmidborne U2 gene is expressed.

Yeast strains were grown in $50 \mathrm{ml}$ of YEPD or synthetic complete media lacking the appropriate amino acids (Sherman et al. $1986)$ to mid-log phase of growth $\left|A_{600}=0.5-1.0\right|$, diluted, shifted to nonpermissive temperature by the addition of prewarmed or prechilled medium, and incubated for the indicated times before RNA extraction or structure probing.

\section{RNA extraction and analysis}

Total RNA was extracted essentially as described previously (Ares and Igel 1990). Cell pellets were resuspended in $0.5 \mathrm{ml}$ of AK buffer $(\mathrm{AK}$ buffer $=1$ gram of triisopropylnaphthalene sulfonic acid, 6 grams of sodium $p$-aminosalicylate, 1.17 gram of sodium chloride, and $6 \mathrm{ml}$ of phenol per $100 \mathrm{ml})$. Hot $\left(65^{\circ} \mathrm{C}\right)$ phenol $(0.5 \mathrm{ml})$ was added, and the mixture was vortexed for 30 $\mathrm{sec}$, incubated at $65^{\circ} \mathrm{C}$ for $30 \mathrm{~min}$, and vortexed twice for $30 \mathrm{sec}$ each. The mixture was spun in a microcentrifuge for $5 \mathrm{~min}$, and the aqueous phase was removed and extracted once with phenol/chloroform/isoamyl alcohol $(25: 24: 1)$ and once with chloroform. Sodium acetate $(\mathrm{pH} 5.2)$ was added to a final concentration of $0.3 \mathrm{M}$, and the RNA was precipitated by the addition of 3 volumes of $95 \%$ ethanol. The pellet was resuspended in water to a nucleic acid concentration of $1.0 \mathrm{mg} / \mathrm{ml}$ $\left(A_{260}=25\right)$.

Primer extensions were as follows for a $20-\mu \mathrm{l}$ reaction: $5-12$ $\mu g$ of total RNA and $0.2 \mathrm{ng}$ of end-labeled oligonucleotide primer in $13 \mu \mathrm{l}$ of water plus $1 \mu \mathrm{l}$ of $10 \times \mathrm{RT}$ buffer $[1.25 \mathrm{M}$ Tris- $\mathrm{Cl}, 175 \mathrm{mM} \mathrm{KCl}(\mathrm{pH} 8.3)]$ was incubated at $65^{\circ} \mathrm{C}$ for $5 \mathrm{~min}$ and then at the appropriate annealing temperature (determined empirically) for an additional $30 \mathrm{~min}$. Six microliters of extension cocktail (per reaction: $1 \mu \mathrm{l}$ of $10 \times \mathrm{RT}$ buffer, $1 \mu \mathrm{l}$ of $0.1 \mathrm{M}$ dithiothreitol, $2 \mu \mathrm{l}$ of $0.1 \mathrm{M} \mathrm{MgCl}_{2}, 1 \mu \mathrm{l}$ of either $2.5 \mathrm{~mm}$ all dNTPs or, in the case of dideoxynucleotide replacement, a mix containing $100 \mu \mathrm{M}$ of the appropriate ddNTP in place of the corresponding dNTP, $0.5 \mu \mathrm{l}$ of $1.0 \mathrm{mg} / \mathrm{ml}$ actinomycin $\mathrm{D}$, and $0.25 \mu \mathrm{l}$ of AMV reverse transcriptase (Life Sciences, 17-22 U/ $\mu \mathrm{l}$ ) was added, and the mixture was incubated at $42^{\circ} \mathrm{C}$ for $30 \mathrm{~min}$. Five microliters of RNase solution $[10 \mathrm{mg} / \mathrm{ml}$ of RNase $\mathrm{A}, 30$ mM EDTA, and $0.6 \mathrm{M}$ sodium acetate $[\mathrm{pH} 5.2)]$ was added. After 5-10 min incubation at $42^{\circ} \mathrm{C}, 15 \mu \mathrm{l}$ of a proteinase $\mathrm{K}$ solution $(10 \mathrm{mg} / \mathrm{ml}$ of proteinase $\mathrm{K}, 0.2 \% \mathrm{SDS}$, and $0.6 \mathrm{M}$ sodium acetate) was added, and samples were incubated for $10 \mathrm{~min}$ at $65^{\circ} \mathrm{C}$. The samples were extracted once with phenol/chloroform/isoamyl alcohol $(25: 24: 1)$ and precipitated with $95 \%$ ethanol. Samples were resuspended in $98 \%$ formamide, $0.1 \times \mathrm{TBE}$, and dyes and electrophoresed on $7.5 \mathrm{M}$ urea $6 \%$ or $8 \%$ polyacrylamide gels. Reference U2 sequence ladders were generated by doping each of four primer extension reactions containing all dNTPs with 1 $\mu l$ of a different ddNTP stock as follows: ddATP and ddGTP,

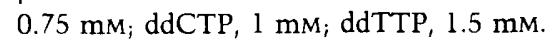

Oligonucleotide primers were labeled at their $5^{\prime}$ ends with $\left[{ }^{32} \mathrm{P} \mid\right.$ phosphate using $\left[\gamma^{-32} \mathrm{P} \mid \mathrm{rATP}\right.$ and polynucleotide kinase. The sequences and the annealing temperatures used are as follows:

23T: GTCTCTTCCCGTCCATTTTATTA $\left(37^{\circ} \mathrm{C}\right)$

MATa1: GTTGCTCTACTTTAGTCAAATTACTTTCC $\left(57^{\circ} \mathrm{C}\right)$

U3 21-mer: CCAAGTTGGATTCAGTGGCTC $\left(58^{\circ} \mathrm{C}\right)$

YSTR: ATTATTTTGGGTGCCAA $\left(37^{\circ} \mathrm{C}\right)$

YU1: TTAACGTCCTTCTACTATTGGAAGCGC $\left(58^{\circ} \mathrm{C}\right)$ 


\section{Splicing extract and substrate preparation}

Yeast whole-cell extracts were prepared as described by Lin et al. (1985) from strain B/81 derivatives grown in YEPD at $30^{\circ} \mathrm{C}$ to an $A_{600}=3.0-5.0$. Actin pre-mRNA substrate was synthesized in vitro using T7 RNA polymerase as described by Milligan and Uhlenbeck (1989). The template was constructed as follows. A derivative of pUC12 carrying a 24-bp insertion of a $T 7$ promoter in the EcoRI site that maintains the $l a c Z^{\prime}$ reading frame for blue/white selection and recreates the EcoRI site in the polylinker was a gift of Dr. Jim Stefano (National Jewish Hospital, Denver, CO). A fragment of the yeast actin gene (Gallwitz and Sures 1980; Ng and Abelson 1980; gift of P. Novick, Yale) was isolated, which extends from the BstYI site at position -81 from the AUG in exon 1 through the 309-nucleotide intron to the HpaII site at position +366 in exon 2, and cloned between the BamHI and Accl sites of the pUC12T7 plasmid. The plasmid DNA was isolated, cleaved with HindIII, and used as a template. The 488-nucleotide transcript was gel purified and used at a sp. act. of $500-2000 \mathrm{cpm} / \mathrm{fmole}$.

\section{Splicing reactions, complex gels, and detection of splicing intermediates}

Splicing reactions were carried out essentially as described by Lin et al. (1985): A 10- $\mu$ l reaction contained $\sim 10-100$ fmoles of substrate, $40 \%$ in splicing extract, $3 \%$ polyethylene glycol, 60 mM potassium phosphate $\{\mathrm{pH} 7.0\}, 2.5 \mathrm{~mm}$ magnesium chloride, $2 \mathrm{~mm}$ spermidine, and $2 \mathrm{mM}$ ATP. GTP was also included at 2 $\mathrm{mm}$. For analysis of splicing substrate reactions, 5- $\mu \mathrm{l}$ samples were incubated in $100 \mu \mathrm{l}$ of stop buffer $(0.3 \mathrm{M}$ sodium acetate, 5 mM EDTA, $0.2 \%$ SDS, and $100 \mathrm{mg} / \mathrm{ml}$ of proteinase $\mathrm{K}$ ) at $65^{\circ} \mathrm{C}$ for $15 \mathrm{~min}$, followed by extraction with an equal volume of acid phenol and precipitation with ethanol. Samples were separated on $6 \%$ polyacrylamide $-7.5 \mathrm{M}$ urea gels, dried, and autoradiographed.

For analysis of splicing complexes, procedures described by Seraphin and Rosbash $(1989,1991)$ were used. Splicing reactions $(5 \mu 1)$ were quenched by the addition of $10 \mu$ l of cold $R$ buffer $[2$ $\mathrm{mm}$ magnesium acetate and $50 \mathrm{mM}$ HEPES$\left.-\mathrm{Na}^{+}(\mathrm{pH} 7.5)\right]$ and 5 $\mu \mathrm{l}$ of total yeast RNA at $1 \mathrm{mg} / \mathrm{ml}$. After $10-15 \mathrm{~min}$ on ice, $5 \mu \mathrm{l}$ of loading buffer $150 \%$ glycerol, $5 \mathrm{~mm}$ EDTA, $0.01 \%$ xylene cyanol) was added, and the samples were immediately loaded and electrophoresed at $100 \mathrm{~V}$ for $15 \mathrm{hr}$ in the cold $\left(4^{\circ} \mathrm{C}-6^{\circ} \mathrm{C}\right)$ on composite acrylamide-agarose gels $(3 \% 60: 1$ acrylamide/bisacrylamide, $0.5 \%$ agarose, $5 \%$ glycerol in $0.5 \times \mathrm{TBE}_{\text {; }}$ Seraphin and Rosbash 1989). During the time course experiments, the quench time is maintained at $10-15 \mathrm{~min}$ and the total electrophoresis time is therefore less for the later time points. The complex gels were dried and autoradiographed. Analysis of substrate reactions within the different complexes was done using electroelution to NA45 DEAE membrane according to Pikielny and Rosbash (1986).

U2 RNA representation in the splicing extracts was monitored by extracting RNA from 100- $\mu$ l aliquots of wild-type and mutant extracts with $400 \mathrm{ml}$ of $\mathrm{AK}$ buffer as described above for whole cells. Primer extension was performed as described above, except that two end-labeled oligonucleotide primers (23T for U2 and YU1 for the U1 internal control) were added to the reaction.

\section{In vivo structure probing}

In vivo structure probing was performed essentially as described (Ares and Igel 1990). Strains were grown at permissive temperature and then shifted to restrictive temperatures for $4 \mathrm{hr}$. Cul- tures were maintained at $A_{600}$ between 0.5 and 1.0 during this time. Ten-milliliter aliquots of culture were incubated for $2 \mathrm{~min}$ at the appropriate temperature with $200 \mu \mathrm{l}$ of a $1: 1$ dilution of DMS in $95 \%$ ethanol. Ten-milliliter ice-cold $2 \mathrm{M} 2$-mercaptoethanol and $5 \mathrm{ml}$ of water-saturated isoamyl alcohol were added to quench the reactions. Cells were pelleted and washed once with $10 \mathrm{ml}$ of ice-cold $1 \mathrm{M} 2$-mercaptoethanol, and total RNA was isolated by using AK buffer as above. To demonstrate that little or no modification occurred during RNA extraction, stop controls were done. The cells were grown at $30^{\circ} \mathrm{C}$ and treated identically, except that the DMS was added after the addition of the isoamyl alcohol and 2-mercaptoethanol.

The sites of modification were mapped by primer extension (Inoue and Cech 1985; Moazed et al. 1986) with the YSTR or $23 \mathrm{~T}$ oligonucleotides as described above.

\section{Acknowledgments}

We thank Carol Dammel for stimulating discussions, Beverly Bonde, Carol Dammel, Sandy Fischer, and John Hughes for comments on the manuscript, and Haller Igel and Larisa Overmier for technical assistance. This work was supported by the $\mathrm{Na}$ tional Institutes of Health (grant GM40478) and a Research Career Development Award (to M. A.). M. Z. was supported in part by a University of California Biotechnology Training Grant, and a Dissertation Year Fellowship from the University of California.

The publication costs of this article were defrayed in part by payment of page charges. This article must therefore be hereby marked "advertisement" in accordance with 18 USC section 1734 solely to indicate this fact.

\section{References}

Abovich, N., P. Legrain, and M. Rosbash. 1990. The yeast PRP6 gene encodes a U4/U6 small nuclear ribonucleoprotein particle (snRNP) protein, and the PRP9 gene encodes a protein required for U2 snRNP binding. Mol. Cell. Biol. 10: 64176425.

Altuvia, S., D. Kornitzer, D. Teff, and A. Oppenheim. 1989. Alternative mRNA structures of the cIII gene of bacteriophage lambda determine the rate of its translation initiation. I. Mol. Biol. 219: 265-280.

Ares, M., Jr., and A. H. Igel. 1989. Phylogenetic comparison of U2 small nuclear RNA sequences suggests a pseudoknotted structure. UCLA Symp. Mol. Cell. Biol. 94: 13-23.

- 1990. Lethal and temperature-sensitive mutations and their suppressors identify an essential structural element in U2 small nuclear RNA. Genes \& Dev. 4: 2132-2145.

Astell, C.R., L. Ahlstromjonasson, M. Smith, K. Tatchell, K.A. Nasmyth, and B.D. Hall. 1981. The sequence of the DNAs coding for the mating-type loci of Saccharomyces cerevisiae. Cell 27: 15-23.

Banroques, J. and J. Abelson. 1989. PRP4: A protein of the yeast U4/U6 small ribonucleoprotein particle. Mol. Cell. Biol. 9: 3710-3719.

Barabino, S., B. Sproat, U. Ryder, B. Blencowe, and A. Lamond. 1989. Mapping U2 snRNP-pre-mRNA interactions using biotinylated oligonucleotides made of 2 '-OMe RNA. EMBO $J$. 8: $4171-4178$

Barabino, S., B. Blencowe, U. Ryder, B. Sproat, and A. Lamond. 1990. Targeted snRNP depletion reveals an additional role for mammalian Ul snRNP in spliceosome assembly. Cell 63: 293-302.

Bond, U. 1988. Heat shock but not other stress inducers leads to 
the disruption of a sub-set of snRNPs and inhibition of in vitro splicing in HeLa cells. EMBO I. 7: 3509-3518.

Cheng, S.C. and J. Abelson. 1987. Spliceosome assembly in yeast. Genes \& Dev. 1: 1014-1027.

Datta, B. and A. Weiner. 1991. Genetic evidence for base pairing between U6 and U2 snRNA in mammalian mRNA splicing. Nature 352: 821-824.

Delannoy, P. and M. Caruthers. 1991. Detection and characterization of a factor which rescues spliceosome assembly from a heat-inactivated HeLa cell nuclear extract. Mol. Cell. Biol. 11: 3425-3431.

Gallwitz, D. and I. Sures. 1980. Structure of a split gene: Complete nucleotide sequence of the actin gene in Saccharomyces cerevisiae. Proc. Natl. Acad. Sci. 77: 2546-2550.

Garcia-Blanco, M., S. Jamison, and P. Sharp. 1989. Identification and purification of a 62,000-dalton protein that binds specifically to the polypyrimidine tract of introns. Genes \& Dev. 3: $1874-1886$.

Guthrie, C. 1991. Messenger RNA splicing in yeast: Clues to why the spliceosome is a ribonucleoprotein. Science 253: $157-163$.

Guthrie, C. and B. Patterson. 1988. Spliceosomal snRNAs. Annu. Rev. Genet. 22: 387-419.

Hamm, J., N.A. Dathan, and I.W. Mattaj. 1989. Functional analysis of mutant Xenopus U2 snRNAs. Cell 59: 159-169.

Hartshorne, T. and N. Agabian. 1990. A new U2 RNA secondary structure provided by phylogenetic analysis of trypanosomatid U2 RNAs. Genes \& Dev. 4: 2121-2131.

Hausner, T.-P., L. Giglio, and A. Weiner. 1990. Evidence for base-pairing between mammalian $\mathrm{U} 2$ and $\mathrm{U} 6$ small nuclear ribonucleoprotein particles. Genes \& Dev. 4: 2146-2156.

Inoue, T. and T. Cech. 1985. Secondary structure of the circular form of the Tetrahymena rRNA intervening sequence: A technique for RNA structure analysis using chemical probes and reverse transcriptase. Proc. Natl Acad. Sci. 82: 648-652.

Keller, E. and W. A. Noon. 1985. Intron splicing: A conserved internal signal in introns of Drosophila pre-mRNAs. Nucleic Acids Res. 13: 4971-4981.

Kramer, A. 1988. Presplicing complex formation requires two proteins and U2 snRNP. Genes \& Dev. 2: 1155-1167.

Lamond, A., B. Sproat, U. Ryder, and J. Hamm. 1989. Probing the structure and function of U2 snRNP with antisense oligonucleotides made of 2'-OMe RNA. Cell 58: 383-390.

Legrain, P. and A. Choulika. 1990. The molecular characterization of PRP6 and PRP9 yeast genes reveals a new cysteine/ histidine motif common to several splicing factors. EMBO $/$. 9: 2775-2781.

Legrain, P., B. Seraphin, and M. Rosbash. 1988. Early commitment of yeast pre-mRNA to the spliceosome pathway. Mol. Cell. Biol. 8: 3755-3760.

Lin, R.-J., A.J. Newman, S.-C. Cheng, and J. Abelson. 1985. Yeast mRNA splicing in vitro. J. Biol. Chem. 260: 1478014792.

Luhrmann, R. 1988. snRNP Proteins. In Structure and function of the major and minor small nuclear ribonucleoprotein particles (ed. M. L. Birnsteil), pp. 71-99. Springer Verlag, Heidelberg.

Masukata, H. and J.-I. Tomizawa. 1986. Control of primer formation for ColEl plasmid replication: Conformational change of the primer transcript. Cell 44: 125-136.

McFarland, G. and J. Abelson. 1990. PRP5: A helicase-like protein required for mRNA splicing in yeast. Proc. Natl. Acad. Sci. 87: 4236-4240.

McPheeters, D., P. Fabrizio, and J. Abelson. 1989. In vitro reconstitution of function yeast U2 snRNPs. Genes \& Dev. 3: $2124-2136$.
Miller, A. 1984. The yeast MATa1 gene contains two introns. EMBO I. 3: 1061-1065.

Milligan, J. and O. Uhlenbeck. 1989. Synthesis of small RNAs using T7 RNA polymerase. Methods Enzmol. 180: 51-62.

Miraglia, L., S. Seiwert, A. Igel, and M. Ares. 1991. Limited functional equivalence of phylogenetic variation in small nuclear RNA: Yeast U2 RNA with altered branchpoint complementarity inhibits splicing and produces a dominant lethal phenotype. Proc. Natl. Acad. Sci. 88: 7061-7065.

Moazed, D., S. Stern, and H. Noller. 1986. Rapid chemical probing of conformation in $16 \mathrm{~S}$ ribosomal RNA and 30S ribosomal subunits using primer extension. J. Mol. Biol. 187: 399416.

Muhich, M. and J. Boothroyd. 1988. Polycistronic transcripts in trypanosomes and their accumulation during heat shock: Evidence for a precursor role in mRNA synthesis. Mol. Cell. Biol. 8: 3837-3846.

Myslinski, E., V. Segault, and C. Branlant. 1990. An intron in the genes for U3 small nucleolar RNAs of the yeast Saccharomyces cerevisiae. Science 247: 1213-1216.

$\mathrm{Ng}, \mathrm{R}$. and J. Abelson. 1980. Isolation of the gene for actin in Saccharomyces cerevisiae. Proc. Natl. Acad. Sci. 77: 39123916.

Pan, Z.-Q. and C. Prives. 1989. U2 snRNA sequences that bind $\mathrm{U} 2$-specific proteins are dispensable for the function of U2 snRNP in splicing. Genes \& Dev. 3: 1887-1898.

Parker, R. and B. Patterson. 1987. Architecture of fungal introns: Implications for spliceosome assembly. In Molecular biology of RNA: New perspectives (ed. $\mathrm{M}$. Inouye and $\mathrm{B}$. Dudockl, pp. 133-149. Academic Press, San Diego, CA.

Parker, R., P. Siliciano, and C. Guthrie. 1987. Recognition of the TACTAAC box during mRNA splicing in yeast involves base pairing to the U2-like snRNA. Cell 49: 229-239.

Patterson, B. and C. Guthrie. 1991. A U-rich tract enhances usage of an alternative $3^{\prime}$ splice site in yeast. Cell 64: 181187.

Pikielny, C.W. and M. Rosbash. 1986. Specific small nuclear RNAs are associated with yeast spliceosomes. Cell 45: 869877.

Pikielny, C.W., B.C. Rymond, and M. Rosbash. 1986. Electrophoresis of ribonucleoproteins reveals an ordered assembly pathway of yeast splicing complexes. Nature 324: 341-345.

Pleij, C., K. Reitveld, and L. Bosch. 1985. A new principal of RNA folding based on pseudoknotting. Nucleic Acids Res. 13: 1717-1731.

Puglisi, I., J. Wyatt, and I. Tinoco. 1988. A pseudoknotted RNA oligonucleotide. Nature331: 283-286.

Ruby, S. and J. Abelson. 1988. An early hierarchic role of Ul small nuclear ribonucleoprotein in spliceosome assembly. Science 242: 1028-1035.

_ 1991. Pre-mRNA splicing in yeast. Trends Genet. 7: 7985.

Ruskin, B., P. Zamore, and M. Green. 1988. A factor, U2AF, is required for $\mathrm{U} 2$ snRNP binding and splicing complex assembly. Cell 52: 207-219.

Seraphin, B. and M. Rosbash. 1989. Identification of functional Ul snRNA-pre-mRNA complexes committed to spliceosome assembly and splicing. Cell 59: 349-358.

- 1991. The yeast branchpoint sequence is not required for the formation of a stable U1 snRNA-pre-mRNA complex and is recognized in the absence of U2 snRNA. EMBO J. 10: 1209-1216.

Sherman, F., G. Fink, and J. Hicks. 1986. Methods in yeast genetics. Cold Spring Harbor Laboratory, Cold Spring Harbor, New York.

Shukla, R., Z. Dominski, T. Zwierzynski, and R. Kole. 1990. 
Inactivation of splicing factors in HeLa cells subjected to heat shock. J. Biol. Chem. 256: 20377-20383.

Shuster, E. O. and C. Guthrie. 1990. Human U2 snRNA can function in pre-mRNA splicing in yeast. Nature 345: 270273.

Steitz, J. A., D. L. Black, V. Gerke, K. A. Parker, A. Kramer, D. Frendewey, and W. Keller.1988. Functions of the abundant U-snRNPs. In Structure and function of the major and minor small nuclear ribonucleoprotein particles (ed. M. L. Birnstiel|, pp. 115-154. Springer Verlag, Heidelberg.

Tschudi, C. and E. Ullu. 1990. Destruction of U2, U4, or U6 small nuclear RNAs blocks trans-splicing in trypanosome cells. Cell 61: 459-456.

Tschudi, C., S. Williams, and E. Ullu. 1990. Conserved sequences in the U2 snRNA genes of Kinetoplastida do not include the putative branchpoint recognition region. Gene 91: 71-77.

Walstrum, S. and O. Uhlenbeck. 1990. Self-splicing RNA of Tetrahymena is trapped in a less active conformation by gel purification. Biochemistry 29: 10573-10576.

Williamson, J., M. Raghuraman, and T. Cech. 1989. Monovalent cation-induced structure of telomeric DNA: The G-quartet model. Cell 59: 871-880.

Woolford, J. 1989. Nuclear pre-mRNA splicing in yeast. Yeast 5: 439-457.

Wu, J. and J. Manley. 1989. Mammalian pre-mRNA branch site selection by $\mathrm{U} 2$ snRNP involves base pairing. Genes \& Dev. 3: 1553-1561.

. 1991. Base pairing between U2 and U6 snRNAs is necessary for splicing of a mammalian pre-mRNA. Nature 352: 818-821.

Xu, Y., S. Petersen-Bjorn, and J. Friesen. 1990. The PRP4 (RNA4) protein of Saccharomyces cerevisiae is associated with the 5 ' portion of the U4 small nuclear RNA. Mol. Cell. Biol. 10: $1217-1225$.

Yost, H. and S. Lindquist. 1991. Heat shock proteins affect RNA processing during the heat shock response of Saccharomyces cerevisiae. Mol. Cell. Biol. 11: 1062-1068.

Zamore, P. and M. Green. 1989. Identification, purification and biochemical characterization of U2 small nuclear ribonucleoprotein auxiliary factor. Proc. Natl. Acad. Sci. 86: 92439247.

Zhuang, Y. and A. M. Weiner. 1989. A compensatory base change in human U2 snRNA can suppress a branch site mutation. Genes \& Dev. 3: 1545-1552.

Zillman, M., M. Zapp, and S. Berget. 1988. Gel electrophoretic isolation of splicing complexes containing $\mathrm{Ul}$ small nuclear ribonucleoprotein particles. Mol. Cell. Biol. 8: 814-821 


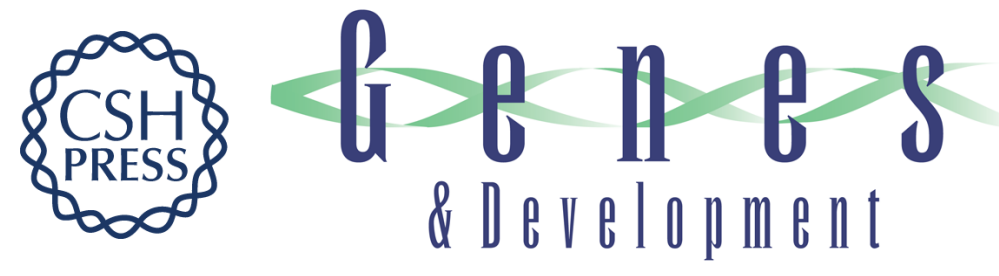

\section{Efficient association of U2 snRNPs with pre-mRNA requires an essential U2 RNA structural element.}

M I Zavanelli and M Ares

Genes Dev. 1991, 5:

Access the most recent version at doi:10.1101/gad.5.12b.2521

References This article cites 61 articles, 28 of which can be accessed free at:

http://genesdev.cshlp.org/content/5/12b/2521.full.html\#ref-list-1

License

Email Alerting

Service

Receive free email alerts when new articles cite this article - sign up in the box at the top right corner of the article or click here.

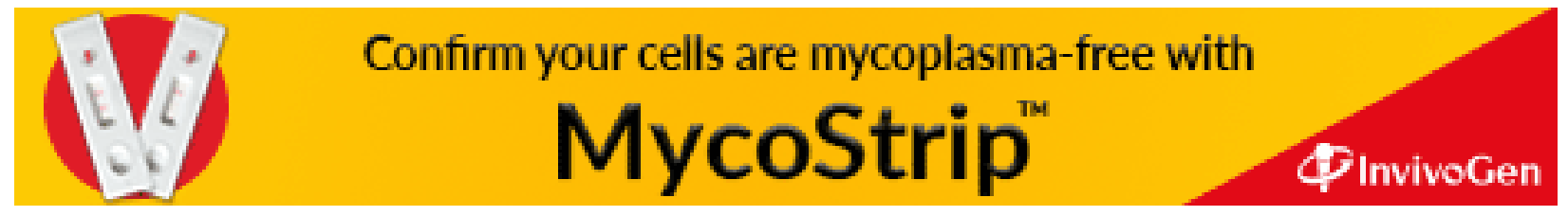

